Article

\title{
Improved Water, Sanitation and Utilization of Maternal and Child Health Services in South Asia-An Analysis of Demographic Health Surveys
}

\author{
Negar Omidakhsh and Ondine S. von Ehrenstein * \\ Fielding School of Public Health, University of California, Los Angeles, CA 90095, USA; nomid@ph.ucla.edu \\ * Correspondence: ovehren@ucla.edu
}

Citation: Omidakhsh, N.; von Ehrenstein, O.S. Improved Water, Sanitation and Utilization of Maternal and Child Health Services in South Asia-An Analysis of Demographic Health Surveys. Int. J. Environ. Res. Public Health 2021, 18, 7667. https:// doi.org/10.3390/ijerph18147667

Academic Editor: Paul B. Tchounwou

Received: 5 May 2021

Accepted: 30 June 2021

Published: 19 July 2021

Publisher's Note: MDPI stays neutral with regard to jurisdictional claims in published maps and institutional affiliations.

Copyright: (c) 2021 by the authors. Licensee MDPI, Basel, Switzerland. This article is an open access article distributed under the terms and conditions of the Creative Commons Attribution (CC BY) license (https:// creativecommons.org/licenses/by/ $4.0 /)$.

\begin{abstract}
Globally, many millions of people still lack access to safe drinking water and sanitation facilities. Here, we examined associations between household availability of improved drinking water and sanitation, respectively, and use of maternal and child health $(\mathrm{MCH})$ services in South Asian countries. Demographic and Health Survey population-based data from Bangladesh, Nepal, India, and Pakistan were used, restricted to women with a child aged $0-36$ months $(n=145,262)$. Types of households' water source and sanitation facilities were categorized based on the World Health Organization and UNICEF's definitions of "improved" and "unimproved". We applied logistic regressions to estimate odds ratios (OR) and 95\% confidence intervals (CI) for improved water and sanitation, respectively, and reported antenatal care visits, having a skilled attendant at birth, and infant vaccination coverage, stratified by maternal education. Among lower educated women, access to improved water source was associated with greater ORs for presence of a skilled attendant at delivery and their children having up-to-date immunizations (OR: 1.29; 95\% CI: 1.17, 1.42). Among lower and higher educated women, improved sanitation (vs. unimproved) was associated with greater ORs for having had adequate antenatal care visits (OR: 1.74; 95\% CI: 1.62, 1.88; OR: 1.71; 95\% CI: $1.62,1.80$ ), and similarly for having had a skilled attendant at birth, and children with up-to-date immunizations. Approaches addressing water/sanitation and $\mathrm{MCH}$ services across sectors could be a suggested public health strategy.
\end{abstract}

Keywords: maternal child health; water; sanitation; health services

\section{Introduction}

Globally, it is estimated that over 700 million people lack access to improved drinking water, and that three billion do not have access to improved sanitation, putting particularly women and children in low- and low middle-income countries at increased risk for adverse health outcomes [1]. As it has been recently highlighted, "water serves as an (often) unacknowledged but essential connecting factor for attaining the different Sustainable Development Goals " [2]; in particular, for attaining Sustainable Development Goal (SDG) 3 targeting the reduction of maternal, neonatal, and child mortality [3].

Infant mortality, a key indicator of population level maternal and child health, has decreased from over 8 million in 1990 to an estimated 4 million annually with a striking gap in rates between countries in northwestern Europe ( 1.5-2 deaths/1000 live births (lb)) and South Asian countries, including India (40 deaths/1000 lb) or Nepal (32/1000 lb) [4-7]. In South Asia, many millions of women and children still lack adequate access to sanitation and safe drinking water as well as access to basic health services including antenatal care, infant immunizations, and the presence of a skilled attendant at birth [8,9]. Indeed, South Asia's achievement of the Millennium Development Goals (MDG) has been mixed. Poverty levels were lowered by $54.7 \%$, exceeding the MDG target of $50 \%$ and the target for universal primary education enrollment was met, but not secondary school enrollment [10]. South Asia as a region also made notable progress in reducing the maternal mortality rate by 
67\% between 1990 and 2015; however, the region was unable to meet the targets set for either child mortality or improved sanitation. Similarly, in 2014 , only $52 \%$ of deliveries were attended by a skilled health professional [10]. While research has demonstrated the importance of water, sanitation, and hygiene (WASH) for maternal and child health $(\mathrm{MCH})[11,12]$, access to improved water and sanitation facilities and use of basic $\mathrm{MCH}$ health services have rarely been considered together. Recently, a handful of programs that aimed to increase women's use of antenatal care services also included water treatment [13] and hygiene education [14,15], pointing towards potential opportunities for $\mathrm{MCH}$ and WASH integrated intervention strategies in resource constraint setting.

\section{Theoretical Background and Study Aims}

According to Fundamental Cause Theory derived from Geoffrey Rose's Cause of Causes, which highlights the role of socioeconomic deprivation as a causal determinant of health $[16,17]$, access to improved water and sanitation facilities, as well as $\mathrm{MCH}$ care access and utilization can be considered intervening mechanisms for underlying material deprivation and structural disadvantage of low-socioeconomic status (SES) women and children in South Asia [16-18]. Additionally, from a socio-ecological systems perspective, dynamic interrelations exist between individual-level care-seeking behavior and community-level services and infrastructure [19]. Thus, elucidating possible linkages between availability of improved water and sanitation with use of $\mathrm{MCH}$ services may lead to refined and thus more effective programs and intervention strategies. Therefore, the aim of this study was to examine associations of household availability of improved drinking water and sanitation, respectively, with reported usage of basic $\mathrm{MCH}$ health services, namely antenatal care, presence of a skilled attendant at birth, and infant vaccination coverage based on a large population sample from the most recent Demographic and Health Surveys (DHS) in four South Asian countries.

\section{Materials and Methods}

\subsection{Study Design and Population}

Data for the present study were obtained from the Demographic and Health Surveys (DHS), which collect nationally representative, individual-level data in low- and middleincome countries through a stratified two-stage cluster design [20]. Within each selected household, questionnaires are administered by in-person interviews for all female residents between the ages of 15-49 years and men aged 15-64 years, and data are collected for children under 5 years of age. Verbal informed consent was obtained from all DHS respondents through the reading of a prescribed statement that is written in the questionnaire by the interviewer. More details on the DHS assessments can be found elsewhere [20].

Data from South Asian countries were included in our study if there was at least one DHS survey assessment available after the year 2000. We excluded Afghanistan and the Maldives as their socioeconomic distributions varied greatly from the other countries; thus, we included women's assessments in Bangladesh, India, Nepal, and Pakistan. As per DHS guidelines on using pooled data, we de-normalized standard weights for each respondent and then re-weighted using UN population division measures on total females aged 15-49 years in the country at the time of survey administration [21,22]. Our current analysis was restricted to women who had a living, singleton birth child, 0-36 months of age at the time of interview.

\subsection{Water and Sanitation}

Households' types of available water sources and sanitation facilities reported in the DHS were categorized based on the World Health Organization (WHO) and United Nations International Children's Emergency Fund (UNICEF) definition of "improved" and "unimproved" (Table 1) [23]. We further examined time (recorded as walking time in minutes) to respondent's water source, re-coded as binary variable (water on premises $=0 \mathrm{~min}$; vs. water not on premises $=1+\mathrm{min})$. However, the majority $(>90 \%)$ of all individuals reported 
having access to water on premises; thus, we conducted a subgroup analysis restricted to women considered particularly vulnerable, i.e., those in the lowest wealth index group with only unimproved water sources available, to assess whether or not walking time to a water source played a role among this group.

Table 1. WHO definitions applied to coding of variables.

\begin{tabular}{|c|c|c|}
\hline Variable & Category & Definition \\
\hline Water ${ }^{a}$ & $\begin{array}{c}\text { Improved } \\
\text { Unimproved }\end{array}$ & $\begin{array}{l}\text { Water that came from a pipe, borehole, } \\
\text { protected dug well, protected spring, } \\
\text { filtration plant, or rainwater } \\
\text { Water that came from unprotected dug well, } \\
\text { unprotected spring, surface water, } \\
\text { vendor-provided water, bottled water, or } \\
\text { tanker truck water }\end{array}$ \\
\hline Sanitation ${ }^{b}$ & $\begin{array}{c}\text { Improved } \\
\text { Unimproved }\end{array}$ & $\begin{array}{l}\text { Pour-flush latrine, simple pit latrine, } \\
\text { ventilated improved pit latrine, pit latrine } \\
\text { with slab, composting toilet, or if toilet } \\
\text { flushed to a public sewer or septic system } \\
\text { Pit latrine without slab, open-pit latrine, } \\
\text { bush, field, no toilet facility, bucket toilet, } \\
\text { traditional dry vault, dry toilet, or toilet that } \\
\text { flushed to "somewhere else" }\end{array}$ \\
\hline Birth Attendant ${ }^{c}$ & $\begin{array}{l}\text { Skilled } \\
\text { Unskilled }\end{array}$ & $\begin{array}{l}\text { Doctor, nurse, midwife, auxiliary midwife, or } \\
\text { other health care professional present } \\
\text { Traditional attendants, friends } \\
\text { and/or relatives }\end{array}$ \\
\hline $\begin{array}{c}\text { Up-to-date } \\
\text { immunizations }\end{array}$ & $\begin{array}{l}0 \text { to }<4 \text { months } \\
4 \text { to }<6 \text { months }\end{array}$ & $\begin{array}{l}\text { BCG (1 dose) } \\
\text { Polio (1 doses) } \\
\text { DPT (1 dose) } \\
\text { BCG (1 dose) } \\
\text { Polio (2 doses) } \\
\text { DPT (2 doses) } \\
\text { BCG (1 dose) } \\
\text { Polio (3 doses) } \\
\text { DPT (3 doses) } \\
\text { BCG (1 dose) } \\
\text { Polio (3 doses) } \\
\text { DPT (3 doses) } \\
\text { Measles (1 dose) }\end{array}$ \\
\hline
\end{tabular}

\subsection{MCH Services}

MCH service utilization was defined based on children's up-to-date immunizations, maternal report of number of antenatal care (ANC) visits and whether a skilled attendant was present at delivery. We considered the WHO's recommendations for routine immunizations when determining whether a child had up-to-date immunizations. Thus, if the child had received appropriate doses of bacille Calmette-Guerin (BCG), diphtheria, pertussis, and tetanus (DPT), and polio and measles vaccinations based on their given age, he/she was considered to have up-to-date immunizations. We were limited to these four vaccines as the DHS data do not contain sufficient information regarding other childhood vaccinations. Similar to other studies, we defined adequate antenatal care as four or more visits during pregnancy [24,25]. We additionally explored any ANC visits ( 1 or more; results not shown) and the recent WHO recommendation of 8 or more ANC visits [26]. Women were coded as having a skilled attendant at delivery if they reported a doctor, 
nurse, midwife, auxiliary midwife, or other healthcare professional were present, while traditional attendants, friends, and/or relatives were considered unskilled (Table 1).

\subsection{Statistical Analyses}

We applied logistic regression models to estimate the odds ratios (OR) and 95\% confidence intervals (CI) for improved (vs. unimproved) water sources and sanitation facilities, respectively, and women's use of health services (as defined in Table 1). Potential confounders were identified a priori, based on previous research examining water and sanitation practices in relation to reproductive and infant health. Our adjusted models included the respondent's age (grouped in 5-year increments), marital status (not married, married or living with partner), the child's birth order, the child's sex, the child's age in months, urban/rural residency, and log GDP per capita. All models including water sources and time to water sources were also adjusted for type of sanitation facilities and the treatment of water (coded as 1 if respondents boiled water, added bleach or chlorine to water, used a water filter or solar disinfection system; otherwise coded as 0 ). Similarly, analyses examining associations with sanitation facilities were adjusted for type of water source and whether or not hand-washing facilities were present on site. We further included fixed effects for country and survey year in order to adjust for unobserved time-invariant confounders specific to each country and temporal trends that are shared across countries. Additional adjustments for partner's age, partner's educational attainment, and women's working status did not meaningfully alter estimates of interest and were thus not retained in our models [27]. All analyses were stratified by maternal educational attainment in order to examine possible effect measure modification ("lower educational attainment", no education or incomplete primary; "higher educational attainment", complete primary, incomplete secondary, complete secondary, or higher). In sensitivity analyses, we additionally stratified by lower vs. higher wealth index. The DHS wealth index quintile is a measure of household SES and is calculated using information regarding household assets (e.g., television or radio), housing construction, water access, and sanitation facilities [28]. In the DHS, each family is assigned to a wealth index quintile; we grouped those in the bottom two quintiles as "lower wealth index" and those in the top three as "higher wealth index". Further sensitivity analyses were stratified by urban and rural residency, and we examined tertiles and quartiles of "time to water source". All analyses were conducted using Stata Statistical Software: Release 14. As the data used for the present study are de-identified and publicly accessible online, the study did not require review from an internal ethics committee.

\section{Results}

Our study sample included data of 145,262 women. Stratifying demographic characteristics of all women by country indicated that mean age, marital status, and distribution of household wealth did not vary considerably between countries (Table 2). Greater proportions of Pakistani women had no education and of women in India and Bangladesh, were residing in rural communities. Additionally, a greater proportion of women with higher education than with lower education had children with up-to-date immunizations, adequate ANC visits, a skilled attendant at delivery, and access to improved sanitation facilities across countries (Table 3 ). 
Table 2. Demographic characteristics of all women (ages 15-49 years) with children, whose last-born child is a singleton birth, alive, and between 0-36 months of age at time of interview.

\begin{tabular}{|c|c|c|c|c|c|}
\hline $\begin{array}{l}\text { Demographic } \\
\text { Characteristics }\end{array}$ & Bangladesh & India & Nepal & Pakistan & All \\
\hline \multirow[t]{2}{*}{ Survey Year } & 2014 & 2015-2016 & 2016 & 2012-2013 & 2012-2016 \\
\hline & $N=4470(\%)$ & $N=132,667(\%)$ & $N=2687(\%)$ & $N=5438(\%)$ & $N=145,262(\%)$ \\
\hline Mean age (SD) & $24.6(0.09)$ & $26.4(0.01)$ & $25.3(0.10)$ & $28.5(0.08)$ & $26.4(0.01)$ \\
\hline \multicolumn{6}{|c|}{ Educational Attainment } \\
\hline No education & $600(13.4)$ & $37,232(28.1)$ & $767(28.5)$ & $2944(54.1)$ & $41,543(28.6)$ \\
\hline $\begin{array}{l}\text { Incomplete } \\
\text { primary }\end{array}$ & $695(15.6)$ & $8069(6.1)$ & $333(12.4)$ & $303(5.6)$ & $9400(6.5)$ \\
\hline Complete primary & $520(11.6)$ & $10,276(7.8)$ & $184(6.9)$ & $500(9.2)$ & $11,480(7.9)$ \\
\hline $\begin{array}{l}\text { Incomplete } \\
\text { secondary }\end{array}$ & $1803(40.3)$ & $50,583(38.1)$ & $741(27.6)$ & $474(8.7)$ & $53,601(36.9)$ \\
\hline $\begin{array}{l}\text { Complete } \\
\text { secondary }\end{array}$ & $328(7.3)$ & $12,232(9.2)$ & $233(8.7)$ & $552(10.2)$ & $13,345(9.2)$ \\
\hline $\begin{array}{l}\text { Higher than } \\
\text { secondary }\end{array}$ & $524(11.7)$ & $14,275(10.8)$ & $429(16.0)$ & $665(12.2)$ & $15,893(10.9)$ \\
\hline \multicolumn{6}{|c|}{ Marital Status } \\
\hline Not married & $51(1.1)$ & $1774(1.3)$ & $12(0.5)$ & $38(0.7)$ & 1875 (1.29) \\
\hline $\begin{array}{l}\text { Married or living } \\
\text { with partner }\end{array}$ & 4419 (98.9) & $130,893(98.7)$ & 2675 (99.6) & $5400(99.3)$ & $143,387(98.7)$ \\
\hline \multicolumn{6}{|c|}{ Residency status } \\
\hline Urban & $1435(32.1)$ & $31,958(24.1)$ & $1535(57.1)$ & $2343(43.1)$ & $37,271(25.7)$ \\
\hline Rural & 3035 (67.9) & $100,709(75.9)$ & $1152(42.9)$ & 3095 (56.9) & $107,991(74.3)$ \\
\hline \multicolumn{6}{|c|}{ Household Wealth Index ${ }^{a}$} \\
\hline Poorest & $933(20.9)$ & $33,095(25.0)$ & $698(26.0)$ & $1186(21.8)$ & $35,912(24.7)$ \\
\hline Poorer & $842(18.8)$ & $30,815(23.2)$ & $582(21.7)$ & $1083(19.9)$ & $33,322(22.9)$ \\
\hline Middle & $865(19.4)$ & $26,749(20.2)$ & $554(20.6)$ & $1042(19.2)$ & $29,210(20.1)$ \\
\hline Richer & $943(21.1)$ & $22,784(17.2)$ & $511(19.0)$ & 1038 (19.1) & $25,276(17.4)$ \\
\hline Richest & $887(19.8)$ & $19,224(14.5)$ & $342(12.7)$ & $1089(20.0)$ & $21,542(14.8)$ \\
\hline
\end{tabular}

${ }^{a}$ The DHS wealth index quintile is a measure of household socioeconomic status (SES) and is calculated using information regarding household assets (e.g., television or radio), housing construction, water access, and sanitation facilities.

Table 3. Frequencies of maternal and child health service utilization and of access to improved water and sanitation by country and education.

\begin{tabular}{|c|c|c|c|c|c|c|c|c|c|c|}
\hline & \multicolumn{2}{|c|}{ Bangladesh } & \multicolumn{2}{|c|}{ India } & \multicolumn{2}{|c|}{ Nepal } & \multicolumn{2}{|c|}{ Pakistan } & \multicolumn{2}{|c|}{ All } \\
\hline & \multicolumn{2}{|c|}{$N=4470(\%)$} & \multicolumn{2}{|c|}{$N=132,667(\%)$} & \multicolumn{2}{|c|}{$N=2687(\%)$} & \multicolumn{2}{|c|}{$N=5438(\%)$} & \multicolumn{2}{|c|}{$N=145,262(\%)$} \\
\hline & Low $^{a}(\%)$ & $\operatorname{High}^{\mathrm{b}}(\%)$ & Low $^{\mathrm{a}}(\%)$ & $\operatorname{High}^{\mathrm{b}}(\%)$ & Low $^{a}(\%)$ & $\operatorname{High}^{\mathrm{b}}(\%)$ & Low $^{\text {a }}(\%)$ & $\operatorname{High}^{\mathrm{b}}(\%)$ & Low $^{a}(\%)$ & $\operatorname{High}^{\mathrm{b}}(\%)$ \\
\hline & $N=1295$ & $N=3175$ & $N=45,301$ & $N=87,366$ & $N=1100$ & $N=1587$ & $N=3247$ & $N=2191$ & $N=50,943$ & $N=94,319$ \\
\hline $\begin{array}{l}\text { Up-to-date } \\
\text { immuniza- } \\
\text { tions }\end{array}$ & $913(70.5)$ & $2649(83.4)$ & $\begin{array}{l}22,145 \\
(48.9)\end{array}$ & $\begin{array}{c}54,947 \\
(62.9)\end{array}$ & $750(68.2)$ & $1262(79.5)$ & $1107(34.1)$ & $1411(64.5)$ & $\begin{array}{c}24,915 \\
(48.1)\end{array}$ & $\begin{array}{l}60,269 \\
(63.9)\end{array}$ \\
\hline $\begin{array}{l}\text { ANC visits } \\
\text { (4 or more) }\end{array}$ & $222(17.1)$ & $1165(36.7)$ & $\begin{array}{l}13,337 \\
(29.4)\end{array}$ & $\begin{array}{l}49,064 \\
(56.2)\end{array}$ & $621(56.5)$ & $1305(82.2)$ & $712(21.9)$ & $1392(63.5)$ & $\begin{array}{l}14,892 \\
(29.23)\end{array}$ & $\begin{array}{l}52,926 \\
(56.1)\end{array}$ \\
\hline $\begin{array}{l}\text { ANC visits } \\
\text { ( } 8 \text { or more) }\end{array}$ & $31(2.4)$ & $246(7.8)$ & $3180(7.0)$ & $\begin{array}{l}17,694 \\
(20.3)\end{array}$ & $40(3.6)$ & $147(9.3)$ & $152(4.7)$ & $517(23.6)$ & $3403(6.7)$ & $\begin{array}{l}18,604 \\
(19.7)\end{array}$ \\
\hline $\begin{array}{l}\text { Presence of } \\
\text { skilled } \\
\text { attendant } \\
\text { at delivery }\end{array}$ & $288(22.2)$ & $1625(51.2)$ & $\begin{array}{l}30,231 \\
(66.7)\end{array}$ & $\begin{array}{l}75,987 \\
(87.0)\end{array}$ & $551(50.1)$ & $1239(78.1)$ & $1413(43.5)$ & $1717(78.4)$ & $\begin{array}{c}32,483 \\
(63.8)\end{array}$ & $\begin{array}{l}80,568 \\
(85.4)\end{array}$ \\
\hline
\end{tabular}


Table 3. Cont.

\begin{tabular}{|c|c|c|c|c|c|c|c|c|c|c|}
\hline & \multicolumn{2}{|c|}{ Bangladesh } & \multicolumn{2}{|c|}{ India } & \multicolumn{2}{|c|}{ Nepal } & \multicolumn{2}{|c|}{ Pakistan } & \multicolumn{2}{|c|}{ All } \\
\hline & \multicolumn{2}{|c|}{$N=4470(\%)$} & \multicolumn{2}{|c|}{$N=132,667(\%)$} & \multicolumn{2}{|c|}{$N=2687(\%)$} & \multicolumn{2}{|c|}{$N=5438(\%)$} & \multicolumn{2}{|c|}{$N=145,262(\%)$} \\
\hline & Low $^{\text {a }}(\%)$ & $\operatorname{High}^{\mathrm{b}}(\%)$ & Low $^{\text {a }}(\%)$ & $\operatorname{High}^{\mathrm{b}}(\%)$ & Low $^{\text {a }}(\%)$ & $\operatorname{High}^{\mathrm{b}}(\%)$ & Low $^{\text {a }}(\%)$ & $\operatorname{High}^{\mathrm{b}}(\%)$ & Low $^{\text {a }}(\%)$ & $\operatorname{High}^{\mathrm{b}}(\%)$ \\
\hline & $N=1295$ & $N=3175$ & $N=45,301$ & $N=87,366$ & $N=1100$ & $N=1587$ & $N=3247$ & $N=2191$ & $N=50,943$ & $N=94,319$ \\
\hline $\begin{array}{l}\text { Improved } \\
\text { water } \\
\text { sources }\end{array}$ & $1176(90.8)$ & 2735 (86.1) & $\begin{array}{c}37,491 \\
(82.8)\end{array}$ & $\begin{array}{c}71,264 \\
(81.6)\end{array}$ & 941 (85.6) & 1343 (84.6) & 2647 (81.5) & 1891 (86.3) & $\begin{array}{l}42,255 \\
(83.0)\end{array}$ & $\begin{array}{c}77,233 \\
(81.9)\end{array}$ \\
\hline $\begin{array}{c}\text { Improved } \\
\text { sanitation } \\
\text { facilities }\end{array}$ & $622(48.0)$ & $2145(67.8)$ & $\begin{array}{l}12,400 \\
(27.4)\end{array}$ & $\begin{array}{c}51,556 \\
(59.0)\end{array}$ & $706(64.2)$ & $1332(83.9)$ & 1975 (60.8) & 1901 (86.8) & $\begin{array}{c}15,703 \\
(30.8)\end{array}$ & $\begin{array}{c}56,943 \\
(60.4)\end{array}$ \\
\hline
\end{tabular}

${ }^{a}$ Low education was defined as none or incomplete primary. ${ }^{b}$ High education was defined as complete primary or higher.

Combined across countries, low-educated women with improved water sources had greater ORs of having children with up-to-date immunizations (OR: 1.29; 95\% CI: 1.17, 1.42) and to have had a skilled attendant at delivery (OR: 1.26 ; 95\% CI: $1.13 ; 1.37)$, compared to low-educated women without access to improved water sources. Among women with higher education, there was little indication that availability of improved water source was associated with $\mathrm{MCH}$ services usage (Table 4).

Table 4. Associations between improved (vs. unimproved) water sources and indicators of maternal and child health care service utilization stratified by maternal education.

\begin{tabular}{|c|c|c|c|c|c|}
\hline MCH Service Indicators & $\begin{array}{l}\text { All } \\
N^{\text {a }}\end{array}$ & $\begin{array}{l}\text { Unimproved } \\
\text { Water }(\%)\end{array}$ & $\begin{array}{c}\text { Improved Water } \\
(\%)\end{array}$ & $\begin{array}{c}\text { Crude OR } \\
\text { (95\% CI) }\end{array}$ & $\begin{array}{c}\text { Adjusted OR } \\
(95 \% \mathrm{CI}) \mathrm{b}\end{array}$ \\
\hline \multicolumn{6}{|c|}{ Lower education (none or incomplete primary) } \\
\hline Up-to-date immunizations & 50,943 & 45.0 & 51.9 & $1.31(1.19,1.45)$ & $1.29(1.17,1.42)$ \\
\hline ANC visits (4 or more) & 50,943 & 32.6 & 30.2 & $0.89(0.80,1.00)$ & $0.90(0.81,1.00)$ \\
\hline ANC visits ( 8 or more) & 50,943 & 7.6 & 7.5 & $0.99(0.83,1.17)$ & $0.99(0.83,1.18)$ \\
\hline Skilled attendant at delivery & 50,943 & 62.7 & 66.2 & $1.16(1.04,1.29)$ & $1.26(1.13,1.37)$ \\
\hline \multicolumn{6}{|c|}{ Higher education (complete primary or higher) } \\
\hline Up-to-date immunizations & 94,319 & 64.5 & 66.7 & $1.10(1.02,1.19)$ & $1.06(0.99,1.15)$ \\
\hline ANC visits (4 or more) & 94,913 & 62.0 & 60.0 & $0.92(0.85,1.00)$ & $0.92(0.85,1.00)$ \\
\hline ANC visits (8 or more) & 94,913 & 25.4 & 24.7 & $0.97(0.88,1.06)$ & $0.97(0.88,1.07)$ \\
\hline Skilled attendant at delivery & 94,913 & 88.4 & 87.9 & $0.94(0.84,1.06)$ & $1.07(0.94,1.21)$ \\
\hline
\end{tabular}

${ }^{a}$ Counts obtained using population weights. ${ }^{b}$ Adjusted for country and year fixed effects, respondent's age, marital status, child's birth order, child's sex, child's age in months, urban/rural residency, treatment of water, type of sanitation, and log GDP per capita.

Having improved (vs. unimproved) sanitation facilities available was associated with greater ORs of child's up-to-date immunizations, adequate ANC visits, and the presence of a skilled birth attendant among women in both lower and higher education groups (Table 5). Interestingly, the frequency of women who reported available improved vs. unimproved sanitation facilities did not differ by type of available water sources (Table S1). In both the lower and higher education categories, the majority of women had access to improved water sources ( $86 \%$ and $82 \%$, respectively); however, availability of improved sanitation facilities was about double in the higher education group (59\%) compared to the lower education group (29\%; Table S2). 
Table 5. Associations between improved (vs. unimproved) sanitation facilities and indicators of maternal and child health care service utilization, stratified by maternal education.

\begin{tabular}{|c|c|c|c|c|c|}
\hline MCH Service Indicators & $\begin{array}{l}\text { All } \\
N^{\text {a }}\end{array}$ & $\begin{array}{c}\text { Unimproved } \\
\text { Sanitation (\%) }\end{array}$ & $\begin{array}{c}\text { Improved } \\
\text { Sanitation }(\%)\end{array}$ & $\begin{array}{c}\text { Crude OR } \\
(95 \% \text { CI })\end{array}$ & $\begin{array}{c}\text { Adjusted } \\
\operatorname{OR}(95 \% \mathrm{CI})^{\mathrm{b}}\end{array}$ \\
\hline \multicolumn{6}{|c|}{ Lower education (none or incomplete primary) } \\
\hline Up-to-date immunizations & 50,943 & 49.3 & 55.6 & $1.29(1.21,1.37)$ & $1.27(1.19,1.36)$ \\
\hline ANC visits (4 or more) & 50,943 & 26.0 & 40.6 & $1.95(1.83,2.09)$ & $1.75(1.62,1.88)$ \\
\hline ANC visits (8 or more) & 50,943 & 6.1 & 10.9 & $1.89(1.68,2.13)$ & $1.67(1.46,1.92)$ \\
\hline Skilled attendant at delivery & 50,943 & 64.6 & 68.8 & $1.21(1.13,1.30)$ & $1.37(1.27,1.47)$ \\
\hline \multicolumn{6}{|c|}{ Higher education (complete primary or higher) } \\
\hline Up-to-date immunizations & 94,319 & 61.5 & 69.1 & $1.40(1.33,1.47)$ & $1.31(1.24,1.38)$ \\
\hline ANC visits (4 or more) & 94,319 & 48.5 & 66.5 & $2.14(2.05,2.24)$ & $1.71(1.62,1.80)$ \\
\hline ANC visits (8 or more) & 94,319 & 16.8 & 29.1 & $2.04(1.91,2.17)$ & $1.64(1.52,1.76)$ \\
\hline Skilled attendant at delivery & 94,319 & 83.7 & 90.3 & $1.85(1.73,1.97)$ & $1.67(1.55,1.79)$ \\
\hline
\end{tabular}

${ }^{a}$ Counts obtained using population weights. ${ }^{b}$ Adjusted for country and year fixed effects, respondent's age, marital status, child's birth order, child's sex, child's age in months, urban/rural residency, type of water source, presence of hand washing facilities on site, and log GDP per capita.

Among the vulnerable subgroup of women in the lower wealth index group who did not have an improved water source, not having water on the premises (vs. with water on premises) was associated with an OR of 0.83 (95\% CI: $0.71,0.97)$ for having had a skilled attendant at birth (Table 6). Sensitivity analyses, stratifying by wealth index instead of educational attainment, resulted in similar odds ratios for models examining associations between type of water source and MCH service usage (Table S3), however, odds ratios related to improved sanitation facility and $\mathrm{MCH}$ service usage were smaller (Table S4). Stratifying by urban/rural residency indicated a similar pattern of associations as the high/low education strati. Dividing "time to water" into tertiles or quartiles resulted in lower point estimates, and widened confidence intervals and did not suggest a doseresponse association (results not shown).

Table 6. Associations between walking time (in minutes) to water source and indicators of maternal and child health care services utilization among vulnerable women ${ }^{\mathrm{a}}$.

\begin{tabular}{cccccccc}
\hline & \multicolumn{2}{c}{ Up-to-Date Immunizations } & \multicolumn{2}{c}{ ANC Visits (4 or More) } & \multicolumn{2}{c}{ Skilled Attendant at Birth } \\
\hline $\begin{array}{c}\text { Time to } \\
\text { water source }\end{array}$ & $\begin{array}{c}N=9836 \\
(\%)\end{array}$ & Crude OR & $\begin{array}{c}\text { Adjusted OR } \\
(95 \% \mathrm{CI})\end{array}$ & Crude OR & $\begin{array}{c}\text { Adjusted OR } \\
(95 \% \mathrm{CI}) \mathrm{b}\end{array}$ & $\begin{array}{c}\text { Crude OR } \\
(95 \% \mathrm{CI}) \mathrm{b}\end{array}$ \\
\hline $\begin{array}{c}\text { Water on premises } \\
(0 \mathrm{~min})\end{array}$ & 27.5 & ref & ref & ref & ref & ref & ref \\
\hline $\begin{array}{c}\text { Water not on } \\
\text { premises }(>0 \text { min })\end{array}$ & 72.4 & $0.88(0.77,1.01)$ & $0.96(0.84,1.10)$ & $0.96(0.82,1.13)$ & $1.12(0.95,1.31)$ & $0.73(0.62,0.85)$ & $0.83(0.71,0.97)$ \\
\hline
\end{tabular}

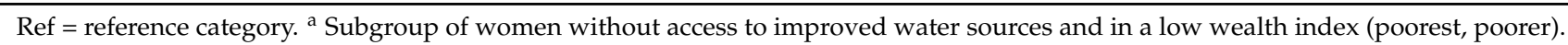

${ }^{\mathrm{b}}$ Adjusted for country and year fixed effects, respondent's age, educational attainment, marital status, urban/rural residency, child's birth order, child's sex, child's age in months, appropriate treatment of water, type of sanitation, and log GDP per capita.

\section{Discussion}

To our knowledge, our study is the first to examine population-level associations between availability of improved water and sanitation facilities, respectively, and the use of $\mathrm{MCH}$ services. Among lower educated women, those with improved water source available had greater ORs for presence of a skilled attendant at delivery and their children having up-to-date immunizations, than those without improved water sources. This may indicate that women with low SES who have no access to improved water may be at particular risk of lacking access to essential $\mathrm{MCH}$ services. Interestingly, access to improved sanitation facilities (vs. unimproved facilities) related to greater ORs for having adequate ANC visits, children with up-to-date immunizations, and a skilled birth attendant for 
both lower and higher educated women. These findings may suggest that increasing access to improved water source among lower socioeconomic groups and to improved sanitation facilitates among all women, may be a strategy that could be linked with access and utilization of $\mathrm{MCH}$ services, thereby contributing on multiple levels to maternal and child health in South Asia.

There are several underlying pathways through which unimproved water and sanitation may relate to lower ORs for utilizing $\mathrm{MCH}$ services, with pathogen transmission playing a possible role. According to the WHO, 829,000 deaths from diarrheal disease were related to the quality of WASH in 2016 [29]. Associations between WASH and disease burden are well established [30-32]. Maternal impaired health status due to WASH related illness may affect her physical ability to access and use $\mathrm{MCH}$ services; this is supported by findings that distance plays a role in likelihood of facility delivery [33] and that good health status in the mother was suggested to be positively associated with antenatal care utilization [34]. Thus, it may be one plausible explanation that women who are ill from contaminated water or non-hygienic sanitation may be less likely to seek care, or attend ANC and vaccination appointments after birth. Caring for ill children or family members may similarly prevent them from seeking or attending adequate services [35]. In our data, improved sanitation was associated with ANC visits among women in both the lower and higher education groups, while improved water only mattered among lower educated women. This finding is in line with a recent study conducted across 41 low- and middleincome countries showing that only unimproved sanitation, and not unimproved water sources, was associated with childhood diarrhea; this study did not stratify by maternal education as we did, and thus could not disentangle possible related differences [11]. Additionally, it is not uncommon for "improved water", based on current definitions, to contain fecal contamination [36], resulting in misclassification of pathogen exposure; however, this is unlikely to explain differential associations by socioeconomic status. Another explanation may relate to place of residence that enables access to improved WASH facilities and $\mathrm{MCH}$ services through infrastructure, and/or co-occurrence of $\mathrm{MCH}$ and WASH programs [37]. For example, a typical community setting may entail governmental and other civil society organizations' programs and may offer a range of programs in support of access to improved WASH and basic MCH services. Moreover, among the women with low SES and without access to improved water sources, those with additional lack of access to a water source on the residential premises had lower OR of having a skilled attendant at birth, when compared to women who had water on the premises. This may indicate a group with very little resources facing multiple constraints in having a skilled attendant at birth, thus pointing out a group for targeted intervention efforts. While there are conceivable linkages between WASH and $\mathrm{MCH}$ services, there are few reports addressing potential benefits and challenges of integrated programming. A few, mostly small, intervention studies examined the usage of antenatal service as an entry to other public health interventions, including water treatment and hygiene education [13], or HIV testing and treatment $[13,15]$. Future operational research is needed to reveal potential benefits and challenges of integrated WASH and $\mathrm{MCH}$ programming.

Several limitations need to be considered. The design of our study is cross-sectional limiting interpretation about directionality of the estimated associations. Our study examined access to improved vs. unimproved water sources and, based on available data, cannot differentiate between the use of different water sources for hygiene practices (washing hands, washing dishes etc.) vs. cooking and other consumption. Although we adjusted for "appropriate treatment of water" which did not appreciably change our findings, we have no information on microbial or toxic contamination of the drinking water or other water quality indicators. Indeed, it has been shown that improved water sources, using a similar definition to the one we applied in our analyses [23], can have similar pathogen levels as unimproved water [36]. Thus, pathogen contamination misclassification might potentially weaken associations. Other desirable information we did not have include mothers' health status or distance to services. While our findings may inform the design 
and implementation of integrated intervention approaches, additional transdisciplinary and operational research including mixed methods research would be warranted to further understand the possible role of WASH in relation to access and utilization of $\mathrm{MCH}$ services, and potential leverage points. Importantly, the COVID-19 pandemic is having substantial impacts, partly in opposite directions, with WASH being scaled up in some areas [38] but not in others, especially not in the most vulnerable constraint resource settings [39,40]; at the same time, research across the globe indicates that access and utilization of $\mathrm{MCH}$ services has been reduced related to the pandemic [41]. These developments are crucial to be considered in the current global health agenda.

\section{Conclusions}

The WHO's "Health in All Policies" approach provides a framework based on the understanding that our greatest health challenges, including health inequities, are highly complex and often linked through social determinants of health, encouraging policy makers to promote health across sectors in public policies to improve maternal and child health equity, targeting the most vulnerable populations. Our findings provide support to the notion that maternal and child health might benefit from approaches across sectors addressing WASH and $\mathrm{MCH}$ services [42].

Supplementary Materials: The following are available online at https://www.mdpi.com/article/ 10.3390/ijerph18147667/s1. Table S1: Cross tabulation of women who have access to improved and unimproved water vs. improved and unimproved sanitation. Table S2: Cross tabulation and Spearman correlation of women who have access to improved and unimproved water and sanitation stratified by education. Table S3: Associations between improved (vs. unimproved) water sources and indicators of maternal and child health care services by DHS wealth index. Table S4: Association between improved (vs. unimproved) sanitation facilities and indicators of maternal and child health care services by DHS wealth index.

Author Contributions: Conceptualization, N.O. and O.S.v.E.; methodology, N.O. and O.S.v.E.; software, N.O.; validation, N.O. and O.S.v.E.; formal analysis, N.O. and O.S.v.E.; writing-original draft preparation, N.O. and O.S.v.E.; writing-review and editing, N.O. and O.S.v.E. All authors have read and agreed to the published version of the manuscript.

Funding: This research received no external funding.

Institutional Review Board Statement: Ethical review and approval were waived for this study, due to the use of publicly available and anonymized secondary data.

Data Availability Statement: All Demographic and Health Survey data used in the present study are available free for download at https:/ / dhsprogram.com (accessed on 1 June 2018).

Conflicts of Interest: The authors declare no conflict of interest.

\section{References}

1. WHO; UNICEF. Progress on Household Drinking Water, Sanitation and Hygiene 2000-2017: Special Focus on Inequalities; United Nations Children's Fund (UNICEF): New York, NY, USA; World Health Organization: Geneva, Switzerland, 2019.

2. UNESCO; World Water Assessment Programme. The United Nations World Water Development Report 2020: Water and Climate Change; United Nations Educational, Scientific and Cultural Organization: Paris, France, 2020.

3. United Nations. Transforming out World: The 2030 Agenda for Sustainable Development; United Nations: New York, NY, USA, 2015.

4. World Health Organization. World Health Statistics 2020: Monitoring Health for the SDGs, Sustainable Development Goals; World Health Organization: Geneva, Switzerland, 2020.

5. GBD 2017 Causes of Death Collaborators. Global, regional, and national age-sex-specific mortality for 282 causes of death in 195 countries and territories, 1980-2017: A systematic analysis for the Global Burden of Disease Study 2017. Lancet 2018, 392, 1736-1788. [CrossRef]

6. GBD 2017 Mortality Collaborators. Global, regional, and national age-sex-specific mortality and life expectancy, 1950-2017: A systematic analysis for the Global Burden of Disease Study 2017. Lancet 2018, 392, 1684-1735. [CrossRef]

7. GBD 2017 DALYs and HALE Collaborators. Global, regional, and national disability-adjusted lif e-years (DALYs) for 359 diseases and injuries and healthy life expectancy (HALE) for 195 countries and territories, 1990-2017: A systematic analysis for the Global Burden of Disease Study 2017. Lancet 2018, 392, 1859-1922. [CrossRef] 
8. GBD 2017 Risk Factor Collaborators. Global, regional, and national comparative risk assessment of 84 behavioural, environmental and occupational, and metabolic risks or clusters of risks for 195 countries and territories, 1990-2017: A systematic analysis for the Global Burden of Disease Study 2017. Lancet 2018, 392, 1923-1994.

9. GBD 2017 SDG Collaborators. Measuring progress from 1990 to 2017 and projecting attainment to 2030 of the health-related Sustainable Development Goals for 195 countries and territories: A systematic analysis for the Global Burden of Disease Study 2017. Lancet 2018, 392, 2091-2138. [CrossRef]

10. UN Economic and Social Commission for Asia and the Pacific. Achieving the Sustainable Development Goals in South Asia: Key Policy Priorities and Implementation Challenges; Economic and Social Commission for Asia and the Pacific (ESCAP): Bangkok, Thailand, 2018; ISBN 978-92-1-120746-0.

11. Geere, J.-A.L.; Hunter, P.R. The association of water carriage, water supply and sanitation usage with maternal and child health. A combined analysis of 49 Multiple Indicator Cluster Surveys from 41 countries. Int. J. Hyg. Environ. Health 2020, 223, 238-247. [CrossRef]

12. Patel, R.; Gupta, A.; Chauhan, S.; Bansod, D.W. Effects of sanitation practices on adverse pregnancy outcomes in India: A conducive finding from recent Indian demographic health survey. BMC Pregnancy Childbirth 2019, 19, 378. [CrossRef]

13. Matanock, A.; Anderson, T.; Ayers, T.; Likicho, L.; Wamimbi, R.; Lu, X.; Emeetai, T.; Kakande, C.; Mutabazi, M.; Quick, R. Integrating Water Treatment into Antenatal Care: Impact on Use of Maternal Health Services and Household Water Treatment by Mothers-Rural Uganda, 2013. Am. J. Trop. Med. Hyg. 2016, 94, 1150-1156. [CrossRef]

14. Routh, J.A.; Loharikar, A.; Chemey, E.; Msoma, A.; Ntambo, M.; Mvula, R.; Ayers, T.; Gunda, A.; Russo, E.T.; Barr, B.T.; et al. Safe Water and Hygiene Integration with Human Immunodeficiency Virus and Antenatal Services: Leveraging Opportunities for Public Health Interventions and Improved Service Uptake. Am. J. Trop. Med. Hyg. 2018, 98, 1234-1241. [CrossRef] [PubMed]

15. Fagerli, K.; Routh, J.; Hancock, W.T.; Hoots, B.; Gunda, A.; Deng, L.; Tippett Barr, B.; Kamb, M.; Quick, R. Impact of program transfer from a non-governmental organization to a district health office: Evaluation of a program integrating water treatment and hygiene kits into reproductive health and HIV services, Machinga District, Malawi, 2010-2012. PLoS ONE 2019, 14, e0219984. [CrossRef] [PubMed]

16. Link, B.G.; Phelan, J. Social conditions as fundamental causes of disease. J. Health Soc. Behav. 1995, 80-94. [CrossRef]

17. Rose, G. Sick individuals and sick populations. Int. J. Epidemiol. 1985, 14, 32-38. [CrossRef]

18. Goldberg, D.S. The implications of fundamental cause theory for priority setting. Am. J. Public Health 2014, 104, 1839-1843. [CrossRef] [PubMed]

19. Bronfenbrenner, U. Ecological systems theory. In Six Theories of Child Development: Revised Formulations and Current Issues; Jessica Kingsley Publishers: London, UK, 1992; pp. 187-249.

20. Corsi, D.J.; Neuman, M.; Finlay, J.E.; Subramanian, S. Demographic and health surveys: A profile. Int. J. Epidemiol. 2012, 41, 1602-1613. [CrossRef]

21. International, I. Demographic and Health Survey Sampling and Household Listing Manual; ICF International: Calverton, MD, USA, 2012.

22. UN Department of Economic and Social Affairs Population Devision. World Population Prospects: The 2017 Revision. 2017. Available online: https:/ / population.un.org/wpp/ (accessed on 13 June 2018).

23. WHO. Progress on Drinking Water, Sanitation and Hygiene: 2017 Update and SDG Baselines; World Health Organization (WHO): Geneva, Switzerland; United Nations Children's Fund (UNICEF): New York, NY, USA, 2017.

24. Yaya, S.; Bishwajit, G.; Ekholuenetale, M.; Shah, V.; Kadio, B.; Udenigwe, O. Timing and adequate attendance of antenatal care visits among women in Ethiopia. PLoS ONE 2017, 12, e0184934. [CrossRef] [PubMed]

25. Heredia-Pi, I.; Serván-Mori, E.; Darney, B.; Reyes-Morales, H.; Lozano, R. Measuring the adequacy of antenatal health care: A national cross-sectional study in Mexico. Bull. World Health Organ. 2016, 94, 452-461. [CrossRef] [PubMed]

26. World Health Organization. WHO Recommendations on Antenatal Care for a Positive Pregnancy Experience; World Health Organization: Geneva, Switzerland, 2016; ISBN 978-92-4-154991-2.

27. Greenland, S.; Daniel, R.; Pearce, N. Outcome modelling strategies in epidemiology: Traditional methods and basic alternatives. Int. J. Epidemiol. 2016, 45, 565-575. [CrossRef]

28. Rutstein, S.; Johnson, K. The DHS Wealth Index. DHS Comparative Reports No. 6; ORC Macro: Calverton, MD, USA, 2004.

29. World Health Organization. Mortality and Burden of Disease from Water and Sanitation. Available online: https://www.who. int/data/gho/indicator-metadata-registry/imr-details/2260 (accessed on 2 May 2020).

30. GBD Diarrhoeal Diseases Collaborators. Estimates of global, regional, and national morbidity, mortality, and aetiologies of diarrhoeal diseases: A systematic analysis for the Global Burden of Disease Study 2015. Lancet Infect. Dis. 2017, 17, 909-948. [CrossRef]

31. GBD 2016 Lower Respiratory Infections Collaborators. Estimates of the global, regional, and national morbidity, mortality, and aetiologies of diarrhoea in 195 countries: A systematic analysis for the Global Burden of Disease Study 2016. Lancet Infect. Dis. 2018, 18, 1211-1228. [CrossRef]

32. GBD 2019 Risk Factors Collaborators. Global burden of 87 risk factors in 204 countries and territories, 1990-2019: A systematic analysis for the Global Burden of Disease Study 2019. Lancet 2020, 396, 1223-1249. [CrossRef]

33. Delele, T.G.; Biks, G.A.; Abebe, S.M.; Kebede, Z.T. Determinants of Health Facility Delivery in Northwest Ethiopia: A CommunityBased Case-Control Study. Int. J. Gen. Med. 2021, 14, 993-1001. [CrossRef] [PubMed] 
34. Halim, N.; Bohara, A.K.; Ruan, X. Healthy mothers, healthy children: Does maternal demand for antenatal care matter for child health in Nepal? Health Policy Plan 2011, 26, 242-256. [CrossRef]

35. Heymann, S.J.; Vo, P.H.; Bergstrom, C.A. Child Care Providers' Experiences Caring For Sick Children: Implications For Public Policy. Early Child Dev. Care 2002, 172, 1-8. [CrossRef]

36. Shaheed, A.; Orgill, J.; Montgomery, M.A.; Jeuland, M.A.; Brown, J. Why "improved" water sources are not always safe. Bull. World Health Organ. 2014, 92, 283-289. [CrossRef]

37. World Health Organization. Global Strategy for Women's and Children's Health. Available online: https://www.who.int/ pmnch/topics/maternal/20100914_gswch_en.pdf?ua=12010 (accessed on 30 June 2020).

38. Islam, S.M.D.; Mondal, P.K.; Ojong, N.; Bodrud-Doza, M.; Siddique, M.A.B.; Hossain, M.; Mamun, M.A. Water, sanitation, hygiene and waste disposal practices as COVID-19 response strategy: Insights from Bangladesh. Environ. Dev. Sustain. 2021, 23, 11953-11974. [CrossRef]

39. McGriff, J.A.; Denny, L. What COVID-19 Reveals about the Neglect of WASH within Infection Prevention in Low-Resource Healthcare Facilities. Am. J. Trop. Med. Hyg. 2020, 103, 1762-1764. [CrossRef] [PubMed]

40. Parikh, P.; Diep, L.; Gupte, J.; Lakhanpaul, M. COVID-19 challenges and WASH in informal settlements: Integrated action supported by the sustainable development goals. Cities 2020, 107, 102871. [CrossRef] [PubMed]

41. Kumar, J. Effect of COVID-19 on maternal and neonatal services. Lancet. Glob. Health 2021, 9, e113. [CrossRef]

42. World Health Organization; United Nations Children's Fund. WASH in Health Care Facilities: Global Baseline Report 2019; WHO: Geneva, Switzerland; UNICEF: New York, NY, USA, 2019. 